\title{
Building Life Cycle Assessment to Evaluate Environment Sustainability of Residential Buildings in Sri Lanka
}

\section{K.S.L. Wickramaratne and A.K. Kulatunga}

\begin{abstract}
The built environment consumes significant amounts of natural resources and energy while being responsible for emitting huge quantities of carbon dioxide into the atmosphere and thereby to become as one of the main contributors for climate change. Therefore, identifying the environmental hotspots from the built environment has become important considering the entire life cycle of the building i.e. cradle-to-gate. Hence the importance of using Building Life Cycle Assessment (LCA) as a tool for evaluating environmental impacts related to the building sector is globally recognized. This paper presents an LCA for a case study of a typical single floor residential building located in Colombo, Sri Lanka. The system boundary of this study is considered as cradle-to-gate. The LCA model is developed using SimaPro 8.5.0. software tool. The results obtained from this LCA study highlighted that building walls as the most significant building component in terms of negative environmental impacts. Hence, more attention needs to be given to external and internal wall components to reduce negative environmental impacts. For further studies, it is recommended to measure the potential to reduce environmental impacts with the use of alternative construction materials and alternative construction practices for building walls in Sri Lanka.
\end{abstract}

Keywords: Life Cycle Assessment (LCA), Building Life Cycle Assessment (BLCA), SimaPro, Residential Building, Environmental Impact.

\section{Introduction}

The development rate of the modern world has paved the way towards the most significant environmental crises we are facing today Climate change [9]. Being the highest consumer of natural resources and energy, the Built Environment has major impacts on the environment [4]. The United Nations Global Status Report 2018 [2] highlighted that built environment is responsible for $36 \%$ of global final energy usage and nearly $40 \%$ of energyrelated carbon dioxide $\left(\mathrm{CO}_{2}\right)$ emission in 2017. Carbon dioxide $\left(\mathrm{CO}_{2}\right)$ is a primary greenhouse gas which leads to climate change.

Hence, the challenge we are facing today is to find tools and techniques that can be used in the construction industry which will help us to be on track to meet the global climate ambitions set forth in the Paris agreement in 2015 [2]. LCA is a scientific tool for assessing the environmental impacts associated with a specific product, process or activity by assembling an inventory of relevant inputs and outputs throughout its life cycle [4]. By the time 1990s, LCA has started spreading in the building sector as a tool to obtain environmental-related impacts of buildings which help to achieve sustainable building practices [12].

Due to the difficulty in comparing the results of LCA studies of similar products, the idea for standardizing LCA methodology was born. There are several LCA guidelines published since the 1990s. The guidelines published by the International Standards Organization (ISO) are recognized as the most commonly used standards worldwide.

Different variations of building LCA has been done in various parts of the world. An LCA study for a typical conventional residential house was conducted in India to evaluate the environmental impacts by considering production and construction phases only [14]. Environmental impacts of different alternative

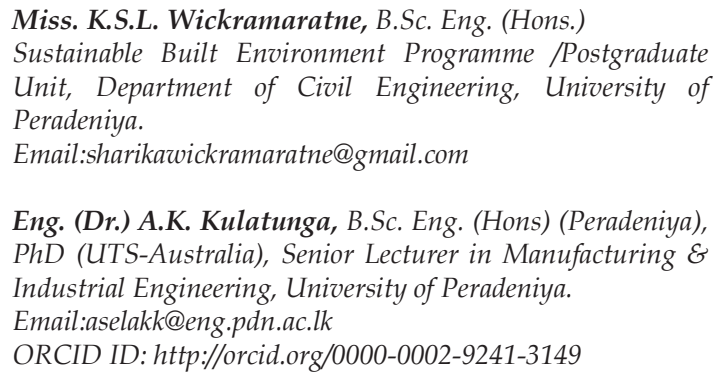

Eng. (Dr.) A.K. Kulatunga, B.Sc. Eng. (Hons) (Peradeniya), PhD (UTS-Australia), Senior Lecturer in Manufacturing $\mathcal{E}$ Industrial Engineering, University of Peradeniya.

Email:aselakk@eng.pdn.ac.lk

ORCID ID: $h$ ttp://orcid.org/0000-0002-9241-3149 
construction technologies have been compared through scenario analysis. Balasbaneh and Bin Marsono [5] compared two alternative IBS frame systems which are made out of concrete and timber. To evaluate the effect of building envelopes on the life cycle energy consumption of high-rise residential buildings a study was done in Jakarta, Indonesia in 2009 [22]. Results of most studies identified that reinforced concrete is the highest contributor to total embodied energy and total embodied carbon of the building [13]. A few studies conluded that building envelop (external and internal masonry work) as the most significant building component [14].

In the Sri Lankan context, few researchers have conducted assessments of life cycle energy and embodied carbon of residential buildings [13]. Since there are no studies for evaluating the overall environmental impacts of typical residential buildings in Sri Lanka, the present study focuses on conducting a benchmark study to fill this gap. This research work aims to conduct a cradle-to-gate life cycle assessment for a $400 \mathrm{ft}^{2}\left(37.16 \mathrm{~m}^{2}\right)$ single floor residential house designed for a low-income family, located in Colombo, Sri Lanka.

\section{Literature Review}

LCA is globally recognized as a scientific tool for assessing the environmental impacts associated with a specific product, process or activity by assembling an inventory of relevant inputs and outputs throughout its life cycle.

The practice of using LCA as an environmental impact assessing tool started in the 1960s under different names. The initial LCA studies were developed as a life cycle costing technique. The first-ever LCA study for evaluating environmental effects of a product was done in 1969, for Coca Cola packaging product life cycle. This research work laid the foundation to modern environmental impacts based on LCA studies.

Due to the conflicts occurred during comparing results of LCA studies of similar products, which were carried out using different methods, the importance of standardizing the LCA methodology was highlighted. There are several LCA guidelines published since the 1990s. The LCA guidelines published by the Society of Environmental Toxicology and Chemistry (SETAC) (1993), Dutch LCA Guidelines, European Environment Agency's LCA guidelines, Canadian Standards Association's LCA guideline (1994), UN Environmental Program (UNEP) LCA guidelines, are few of the well-known guidelines for Life-cycle Assessments. However, the guidelines published by the International Standards Organization (ISO) are recognized as the most commonly used standards worldwide.

By the 1990s, LCA has been started spreading in the building sector as a tool to obtain environmental-related impacts of buildings which help to achieve sustainable building practices [12]. The LCA study of a residential building in Sweden conducted by Adalberth in 1997 [3], can be identified as one of the earliest building LCA studies [1].

There are different variations for LCA studies. Some LCA studies focus on analysing environmental impacts associated with building life cycle while some studies focus only on embodied energy and energy consumption of the building. Some studies analyse a whole building considering one typical building of their region as the case study while some LCA studies focus on construction material and the potential of reducing impacts with the use of alternative construction material and technologies.

In 2012, an LCA study for a typical conventional residential house was conducted in India to evaluate the environmental impacts by considering production and construction phases only [14]. Similar studies have been conducted in Philippines [18] and Italy [6].

A scenario analysis was conducted in the Philippines for a low-rise residential building with three identified alternative construction technologies, named cement-bamboo frames, soil-cement blocks and coconut board-based houses through LCA [18]. A house with clay brick walls and clay roof tiles were compared with a house with concrete block walls and concrete roof by Utama and Gheewala in 2008 [21]. Environmental impacts of different alternative construction technologies have been compared through scenario analysis. In 2012, Balasbaneh and Bin Marsono [5] compared two alternative IBS frame systems made out of concrete and timber.

There are some studies that conducted an LCA study only on one specific building component. To evaluate the effect of building envelopes on the life cycle energy consumption of high-rise residential buildings a study was done in Jakarta, Indonesia in 2009 [22]. For this study clay bricks, walls and gypsum plasterboard and air gap in between were used as two apartment envelope materials [22]. To identify the most 
environmentally friendly solutions for external walls of buildings, a detailed review using the results of more than ten years of international research studies was conducted by Silvestre et al. in 2010 [19].

Several studies have evaluated energy consumption throughout the building's life cycle. Monahan and Powell [16] conducted a scenario Analysis of three different affordable, low energy houses, with similar floor areas and different modular frame systems to evaluate the embodied carbon and energy analysis of modern methods of construction in housing. In 2007, Asif et al. [4] conducted a study to evaluate the embodied energy and associated environmental impacts of five construction materials for a typical dwelling house located in Scotland. The analysed materials included timber, glass, concrete, ceramic tiles and aluminium.

Most of the research study results identified that reinforced concrete is the highest contributor to total embodied energy and total embodied carbon of the building [4], [13], [16]. It also showed that the operational phase consumes the highest energy throughout the 50 years life span of buildings [1]. The study conducted by Reddy and Palaniappan in 2012 concluded that building envelops (external and internal masonry work) as the most significant building component [14]. It also showed that clay-based products work much better than cement-based products throughout the whole building life cycle [1], [21].

In the post-civil war era, Sri Lankan construction industry has developed in an unprecedented scale, both in commercial and residential sectors. Even successive governments of Sri Lanka have initiated many housing projects for urban and rural communities during this period.

The Sri Lankan tea plantation sector provides a significant share of the nation's economy. Few rural housing development projects have been initiated for the tea plantation workers and their families in the Central and Uva Provinces in Sri Lanka. The project launched in 2016 with donations provided by the Indian government aimed at constructing 4,000 housing units for the plantation community. This project initiated as part of the overall commitment of 50,000 houses by the Government of India. The United Nations Human Settlements Programme (UNHabitat), Ministry of Hill Country New Villages, Infrastructure and Community Development (Government of Sri Lanka) and few other international and national organizations have also partnered this project [20].

The Indian government also funded the project for constructing of 43,000 housing units for Internally Displaced Persons (IDPs) following the war in the North and Eastern Provinces in 2012. UN-Habitat, National Housing Development Authority (NHDA) and Habitat for Humanity Sri Lanka (HFHSL) and few other organizations have partnered this project.

The recent Uda Gammana project launched around 2016 under the Housing and Construction Ministry of the Sri Lankan government aiming to spend Rs. 26 billions. This large human settlement project aimed to construct 2500 Uda Gammana (i.e. mini rural housing development projects) in the first phase. The government also planned to construct 20,000 Uda Gammana by 2025 to give shelter for all [8].

Even though these projects plan to construct housing units on the scale of thousands, the lack of attention towards environmental sustainability raises serious concerns among the communities.

Therefore, it is of paramount importance to start the dialogue on the environmental sustainability of the built environment, especially for low-income housing projects due to the large scale of the projects which will become a reality soon.

In the Sri Lankan context, a few researchers have conducted assessments of life cycle energy and embodied carbon of residential buildings [13]. However, no research studies were found for evaluating the cradle-to-gate, environmental impacts of residential buildings in Sri Lanka. Hence, this paper presents a case study as a benchmark study to fill this gap by conducting a cradle-to-gate life cycle assessment of a $400 \mathrm{ft}^{2}$ $\left(37.16 \mathrm{~m}^{2}\right)$ single floor, low-cost residential house, located in Colombo, Western Province of Sri Lanka.

\section{Methodology}

LCA is a technique for assessing the environmental burdens associated with a specific product, process or activity by identifying and quantifying energy and materials used and wastes released to the environment. This is done by assembling an inventory of relevant inputs and outputs throughout its life cycle [4]. 
A framework for conducting LCA work is given in the ISO 14040 (1997) standard. ISO 14040 defines LCA as a technique for assessing the potential environmental aspects associated with a product (or service) by compiling an inventory of relevant inputs and outputs, evaluating the potential environmental impacts associated with these inputs and outputs, and interpreting the results of the inventory and impact phases in relation to the objectives of the study.

Generally, there are four major steps necessary for a complete life cycle study [14].

I. Goal and Scope definition: The initial phase consists of defining the scope of the study including the definition of the functional unit and the system boundary.

II. Life cycle inventory: This step involves the preparation of Life Cycle Inventory (LCI). This phase consists of data collection and calculations to quantify the material and energy input and outputs of the building life cycle.

III. Life cycle impact assessment: This phase evaluates the significance of potential environmental impacts using the LCI data.

IV. Interpretation: This is the final phase in the LCA framework. The results of Life Cycle Impact Assessment (LCIA) will be given and then the conclusions and recommendations based on that will be given.

Since the life span of residential buildings in Sri Lanka varies from region to region based on the construction technology, the system boundary of this study is chosen as cradle-to-gate. The quantity of materials required for this residential building construction work is calculated using the available drawings, Institute for Construction Training and Development (ICTAD) specifications for Building Works-volume 1 [15] and Building Schedule of Rates-2019 Document [7]. The LCA model is developed using SimaPro 8.5.0. software tool. Eco-invent database and the data from previous LCA studies which were conducted by the University of Peradeniya were used for this study.

\subsection{Goal and Scope Definition}

The goal of this research study is to evaluate the environmental impacts of a typical Sri Lankan residential house which is built using economical construction materials. The scope boundary of this study which covers cradle to gate is presented in Figure 1. Most of the largescale social housing projects developed in Sri Lanka has a gross floor area of $400 \mathrm{ft}^{2}\left(37.16 \mathrm{~m}^{2}\right)$. Hence, one house with a total floor area of 400 $\mathrm{ft}^{2}\left(37.16 \mathrm{~m}^{2}\right)$ is defined as the functional unit for building this study.

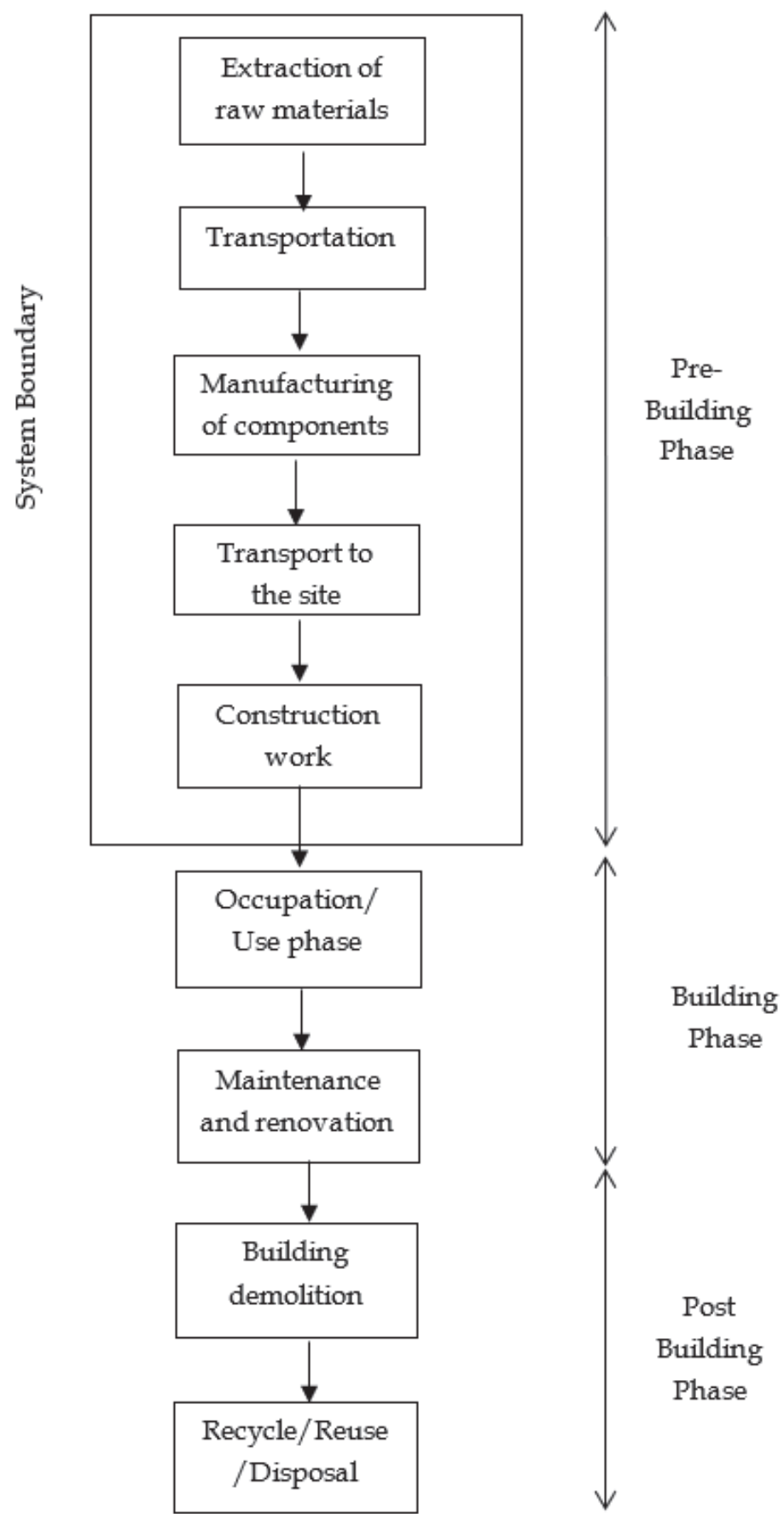

Figure 1 - System Boundary for the Study 
3.2 Life Cycle Inventory and Data Sources For developing a Life Cycle Inventory (LCI), all the relevant inputs and outputs (such as raw materials, energy, wastage, auxiliary materials etc.) within the selected system boundary need to be collected. For developing the SimaPro model, the building is divided into seven components. Each component is defined as an assembly of its constituent materials and processes involved. Building components and materials used for the low-cost residential building are presented in Table 1.

For this typical residential building construction work, all the necessary AutoCAD drawings were drawn by a chartered architect, including the ground floor plan, foundation design, roof design etc. The required amounts of construction materials, such as the number of cement blocks, ceramic tiles, asbestos roofing sheets, were calculated using the floor area/ roof area values provided in the AutoCAD drawings. All the calculations were done using Microsoft Excel spreadsheet program. The summarized life cycle inventory data are presented in Table 2.

The standard cement:sand ratio values mentioned in the ICTAD specifications for Building Works-volume 1 [15] were used for evaluating raw material quantities (such as cement, sand, water, metal etc.) used for mortar for blockwork, rubble foundation work and wall plastering work etc. Building Schedule of Rates-2019 document [7] was also used. Material coverage data which are available in technical specification data sheets were used to calculate the required amount of materials for finishing works including emulsion paint, primer, skim coat, tile adhesive etc. The transportation data for delivering each construction material to the specified site location was also added into each assembly (building component) individually. It is assumed no electrical/mechanical equipment is involved for this construction work and only manual labour is involved.
Table 2 - Summarized Life Cycle Inventory Data

\begin{tabular}{|c|c|c|}
\hline Material & Unit & Quantity \\
\hline Rubble stones & $\mathrm{kg} / \mathrm{FU}$ & 3646.09 \\
\hline Cement & $\mathrm{kg} / \mathrm{FU}$ & 4579.43 \\
\hline Sand & $\mathrm{kg} / \mathrm{FU}$ & 10237.69 \\
\hline $\begin{array}{c}\text { Metal - crushed } \\
\text { stones }\end{array}$ & $\mathrm{kg} / \mathrm{FU}$ & 5281.85 \\
\hline Water & $\mathrm{kg} / \mathrm{FU}$ & 7766.77 \\
\hline $\begin{array}{c}\text { Cement Blocks } \\
(200 \text { mm })\end{array}$ & $\mathrm{Nos} / \mathrm{FU}$ & 876 \\
\hline $\begin{array}{c}\text { Cement Blocks } \\
(100 \text { mm })\end{array}$ & $\mathrm{Nos} / \mathrm{FU}$ & 360 \\
\hline Putty & $\mathrm{kg} / \mathrm{FU}$ & 181.77 \\
\hline Primer paint & $\mathrm{kg} / \mathrm{FU}$ & 29.69 \\
\hline $\begin{array}{c}\text { Weather bond } \\
\text { paint }\end{array}$ & $\mathrm{kg} / \mathrm{FU}$ & 18.71 \\
\hline Emulsion paint & $\mathrm{kg} / \mathrm{FU}$ & 24.06 \\
\hline Tile adhesive & $\mathrm{kg} / \mathrm{FU}$ & 8.45 \\
\hline Ceramic tile & $\mathrm{Nos}$ & 26 \\
\hline Timber & $\mathrm{kg} / \mathrm{FU}$ & 174.02 \\
\hline PVC & $\mathrm{kg} / \mathrm{FU}$ & 181.01 \\
\hline Glass & $\mathrm{kg} / \mathrm{FU}$ & 70.92 \\
\hline Asbestos & $\mathrm{kg} / \mathrm{FU}$ & 1301.4 \\
\hline Brass & $\mathrm{kg} / \mathrm{FU}$ & 8.38 \\
\hline Craft paper & $\mathrm{kg} / \mathrm{FU}$ & 9.34 \\
\hline
\end{tabular}

Table 1 - Building Components and Materials for the Low-Cost House

\begin{tabular}{|c|c|c|c|c|c|c|}
\hline \multicolumn{2}{|c|}{ Building Components } \\
$\begin{array}{c}\text { Rubble } \\
\text { foundation }\end{array}$ & $\begin{array}{c}\text { Floor \& } \\
\text { floor } \\
\text { finishes }\end{array}$ & $\begin{array}{c}\text { External } \\
\text { walls }\end{array}$ & $\begin{array}{c}\text { Internal } \\
\text { walls }\end{array}$ & Doors & Windows & Roof \\
\hline $\begin{array}{c}\text { Rubble } \\
\text { masonry } \\
\text { work }\end{array}$ & $\begin{array}{c}\text { Concrete } \\
\text { floor }+ \\
\text { Rendering } \\
\text { with tiled } \\
\text { bathroom }\end{array}$ & $\begin{array}{c}\text { Cement } \\
\text { block walls } \\
(200 \mathrm{~mm})\end{array}$ & $\begin{array}{c}\text { Cement } \\
\text { block walls } \\
(100 \mathrm{~mm})\end{array}$ & $\begin{array}{c}\text { Timber } \\
\text { main door, } \\
\text { PVC } \\
\text { internal } \\
\text { doors }\end{array}$ & $\begin{array}{c}\text { Timber + } \\
\text { Glass }\end{array}$ & $\begin{array}{c}\text { Asbestos } \\
\text { roof }\end{array}$ \\
\hline
\end{tabular}




\subsection{Life Cycle Impact Assessment}

For building the SimaPro model, the house is divided into seven components. Rubble foundation, floor and floor finishes, external walls, internal walls, doors, windows and roof. Each component is defined as an assembly of its constituent materials and processes involved. SimaPro 8.5.0. software tool consists of many LCI databases. The Eco-Invent database was used for this study. The databases developed for local construction materials including clayroof tiles [17] and ceramic floor tiles [10] were also used.

IPCC 2013-GWP and ReCiPe Endpoint $(\mathrm{H})$ is used for this impact assessment. ReCiPe method is used to transform the long list of life cycle inventory results into a limited number of indicator scores. These indicator scores express the relative severity on an environmental impact category. In the first level of ReCiPe method, life cycle inventory data is translated into eighteen midpoint indicators. Further, these eighteen impacts are aggregated into three end point indicators named 'Human health', 'Eco-system' and 'Resource' for damage assessment.

\section{Case Study}

The case study presented in this study is based on an low-cost residential building envelop which is designed to construct in Colombo, Sri Lanka. A single storey, two-bedroom house with $400 \mathrm{ft}^{2}\left(37.16 \mathrm{~m}^{2}\right)$ floor area was used as the model for this case study. Figure 2 and Figure 3 show the plan view and the $\mathrm{X}-\mathrm{X}$ cross section of the case study residential building, respectively.

The main construction materials for this residential building are given below.

The foundation for the building is based on general rubble masonry work. The house consists of a concrete floor with cement rendering and a bathroom with a tiled floor. The external and internal walls are made out of cement blocks with $200 \mathrm{~mm}$ and $100 \mathrm{~mm}$ thickness, respectively. A timber main door and PVC internal doors with windows made out of timber and glass are used. The asbestos roof is used to achieve the economic advantages for this construction.

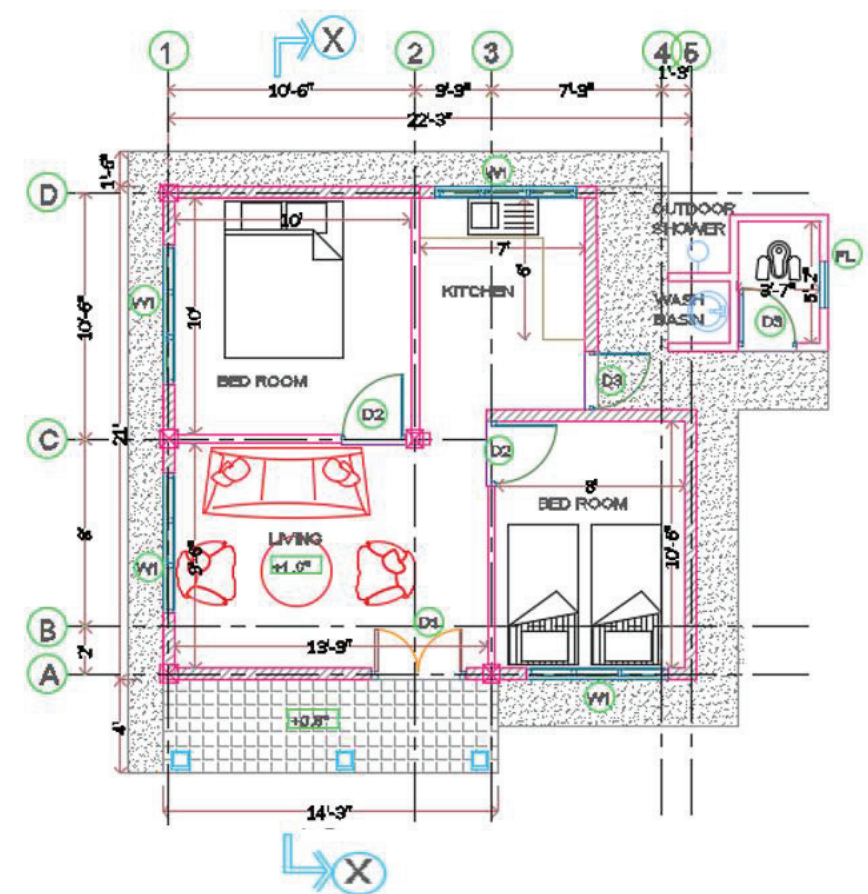

Figure 2 - Plan View of the Building

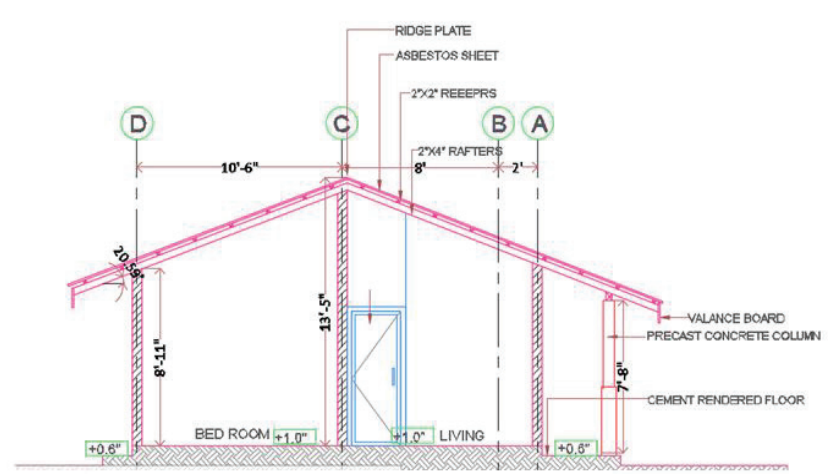

Figure 3 - X-X Cross Section of the Building

\section{Results}

LCIA was done by using the following two standard methods.
I. IPCC 2013 GWP 100a
II. ReCiPe Endpoint $(\mathrm{H})$

\subsection{Analysis on Results of IPCC GWP 100a Method}

Global warming potential (GWP) is one of the most important environmental impact categories in the construction sector. The IPCC GWP 100a method gives a measure for 100-year time horizon GWP relative to $\mathrm{CO}_{2}$. Figure 4 shows the contribution of building components towards GWP. According to the graph given in Figure 4, 
the external walls contribute $100 \%$ (3.58E4 $\mathrm{kg} \mathrm{CO}_{2} \mathrm{eq}$ ) for GWP while internal walls contribute $57.56 \%$ (2.06E4 $\left.\mathrm{kg} \mathrm{CO} \mathrm{CO}_{2} \mathrm{eq}\right)$ for GWP. In this case study, the external walls of the building are made out of $200 \mathrm{~mm}$ thick cement block work and internal walls are made out of $100 \mathrm{~mm}$ thick cement blockwork. This result shows that the building walls (exterior and interior masonry work) is the most significant component in terms of GWP.

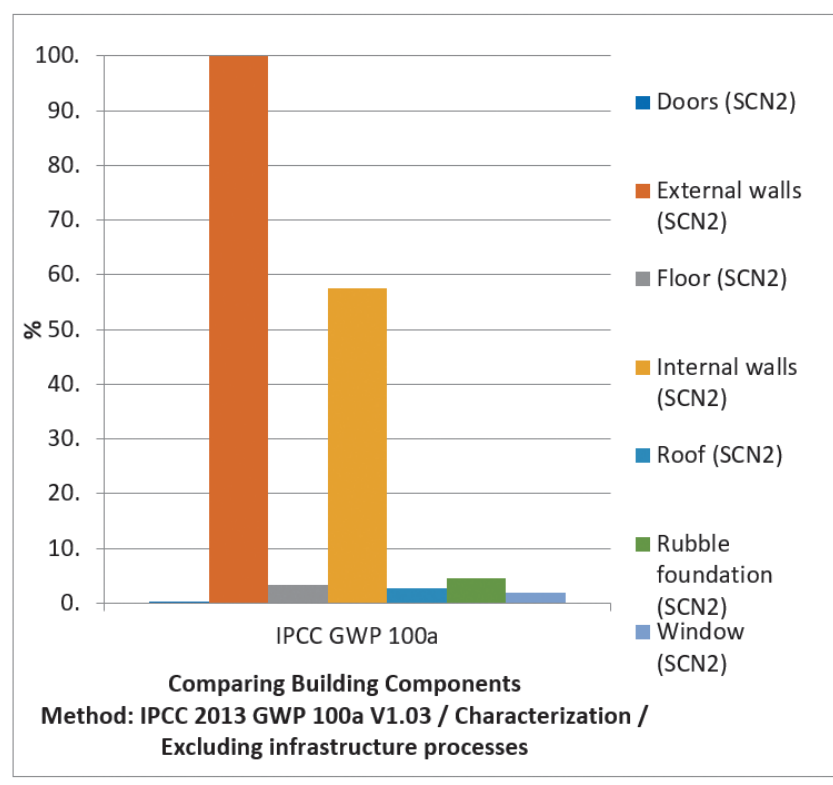

Figure 4 - Building Component wise Contribution to the Global Warming Potential (GWP)

\subsection{Analysis on Results of ReCiPe Method} $\mathrm{ReCiPe}$ is another method for assessing the environmental impacts of the LCA. In this method, LCIA translates emissions into a limited number of environmental impact scores named characterization factors. The two main approaches for deriving characterization factors are named Midpoint level and Endpoint level. ReCipe calculates:

- 18 Midpoint indicators \&

- 3 Endpoint indicators

Midpoint results are more comprehensive while endpoint results are concise. Midpoint analysis is more useful for Eco-Design purposes because it analyses seventeen single environment problems such as climate change, ozone layer depletion and human toxicity. Endpoint indicators are obtained by aggregating all seventeen midpoint indicators into three impact indicators that represent overall impacts on human health, eco-system and resource depletion.

The relative distribution of ReCiPe Midpoint environmental indicators by building components is shown in Figure 5. According to the percentage values obtained, external walls show more than $50 \%$ contribution to all eighteen indicators except 'Agricultural land occupation' with $40 \%$ and $15 \%$ contribution for 'metal depletion', respectively. Hence, building external walls are identified as the most significant building component in terms of environmental impacts. Building internal walls result shows the second-highest contribution.

In Figure 6a, the damage assessment results are given by aggregating all seventeen environmental impact categories caused by building components into three ReCiPe Endpoint indicators named 'Human health', 'Eco-system' and 'Resource'. The results of the weighting of these three damage categories are given in Figure $6 \mathrm{~b}$. The results indicate that External wall component as the most significant building component with the highest contribution to all three damage categories including $58.9 \% \quad(1.42 \mathrm{kPt})$ contribution to 'Human health', 56\% (0.7204 kPt) contribution to 'Ecosystems' and $59.8 \% \quad(0.7014 \quad \mathrm{kPt})$ contribution to 'Resources' categories. Based on the results, internal walls component show the second-largest contribution with 33.3\% (0.8045 $\mathrm{kPt}), 32 \%(0.4119 \mathrm{kPt})$, and $32.8 \%(0.3845 \mathrm{kPt})$, contributions to 'Human health', 'Ecosystems' and 'Resources' categories, respectively. Hence it is evident that, during the eco-design process, more attention needs to be given to the external and internal wall component of the building.

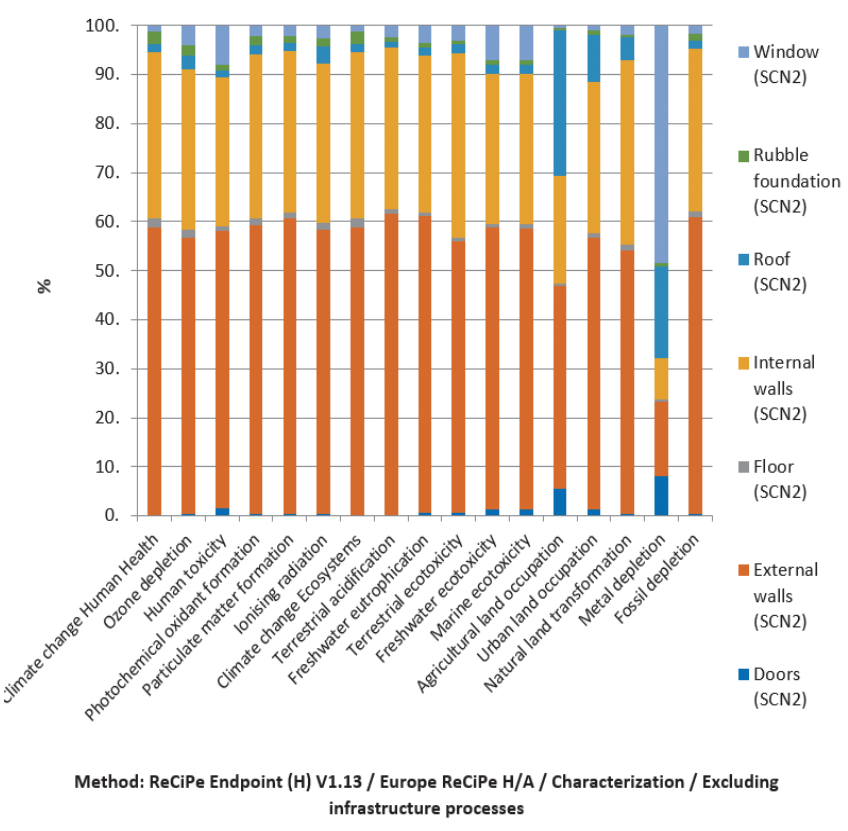

Figure 5 - Building Component wise Environmental Impact Results with Regard to ReCiPe Midpoint (H) Method 


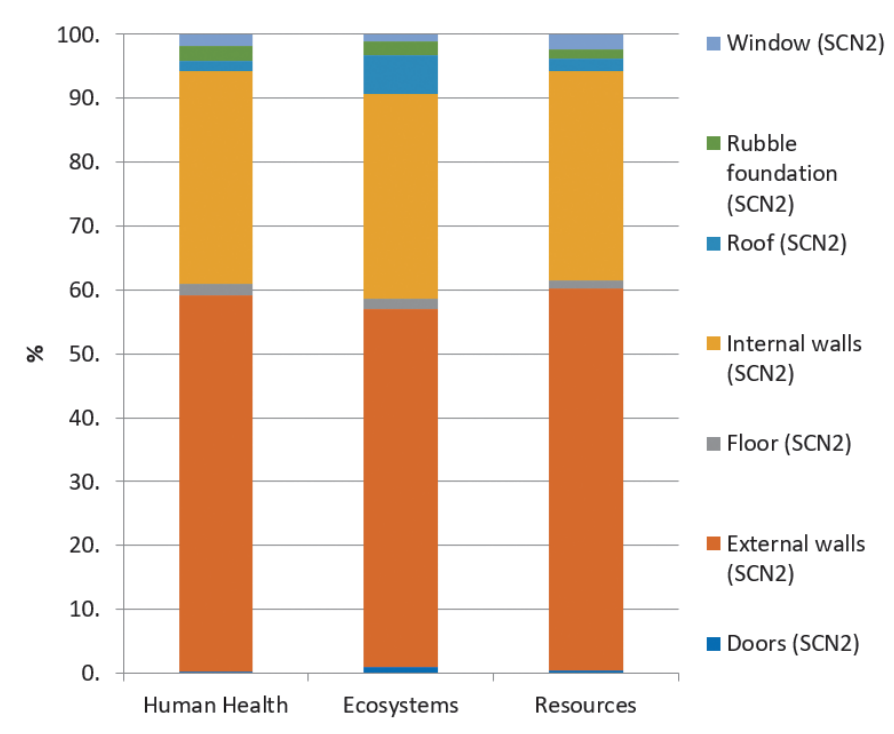

Method: ReCiPe Endpoint (H) V1.13 / Europe ReCiPe H/A / Damage assessment / Excluding infrastructure processes

Figure 6a - Building Component wise Environmental Impact Results with Regard to ReCiPe Endpoint $(\mathrm{H})$ Method

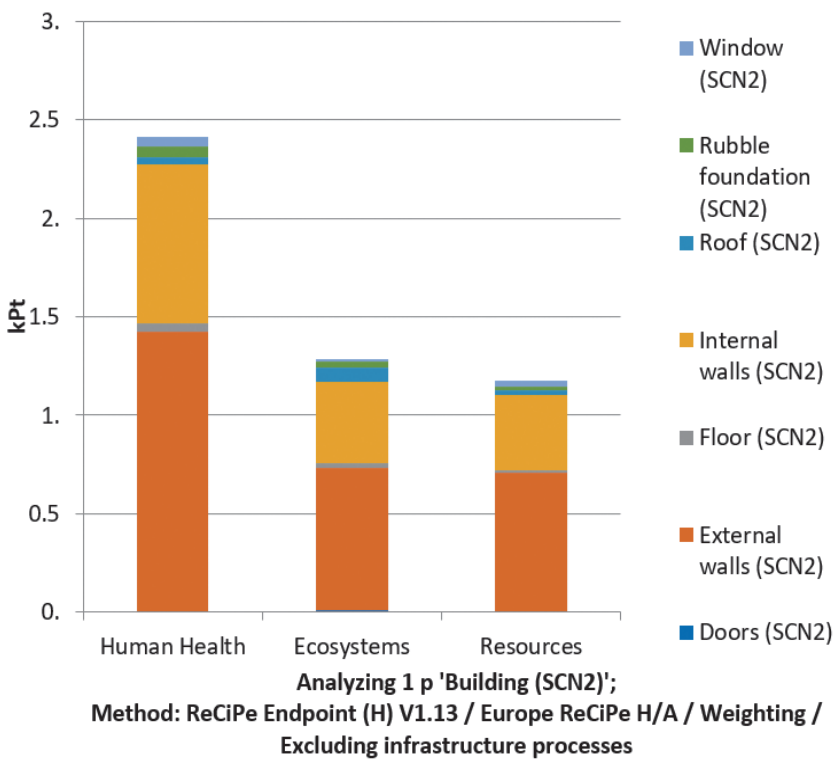

Figure 6b - Building Component wise Weighted Results with Regard to the ReCiPe Endpoint(H) Method

\section{Conclusion}

This paper studied the environmental impacts of typical residential building construction which is designed for a low-income family in Colombo, Sri Lanka. The analysis was done using the LCA software tool 'SimaPro 8.5.0.

According to the IPCC GWP 100 method, the external walls contribute $100 \% \quad(3.58 \mathrm{E} 4 \mathrm{~kg}$
$\left.\mathrm{CO}_{2} \mathrm{eq}\right)$ for GWP while internal walls contribute $57.56 \%$ (2.06E4 $\mathrm{kg} \mathrm{CO} 2 \mathrm{eq})$ for GWP. The analysis on results of ReCiPe Midpoint method gives, external walls displays more than $50 \%$ contribution to all eighteen indicators except 'Agricultural land occupation' with 40\% and $15 \%$ contribution for 'Metal depletion' respectively. The results of the ReCiPe Endpoint method showed a 58.9\% (1.42 kPt) contribution to 'Human health' and 56\% $(0.7204 \mathrm{kPt})$ contribution to 'Ecosystems' and $59.8 \%(0.7014 \mathrm{kPt})$ contribution to 'Resources' categories from the external walls component. Internal walls show the second largest contribution to 'Human health', 'Ecosystems' and 'Resources' categories respectively.

All these LCA study results highlight that the most significant building component is building walls (exterior and interior masonry work). Hence it is recommended to carry out further studies to identify alternative construction materials and alternative building construction practices for building walls that may result in lower negative impacts on the environment. The scope of this work is limited to cradle-to-gate of the residential building life cycle. It is also assumed that no electrical/mechanical equipment is involved for this construction work and only manual labour is involved.

This knowledge can be used for future largescale human settlement projects in the local context. This knowledge can also be extended to achieve environmental sustainability in highrise economical and residential building construction works. Hence, using this knowledge for the advancement of future works will reassure the environmental sustainability of the built environment.

\section{Acknowledgement}

Authors' sincere gratitude goes to the research staff at Sustainable Design \& Manufacturing (SDM) Lab of the Department of Manufacturing \& Industrial Engineering (DMIE) at the Faculty of Engineering, University of Peradeniya, Sri Lanka. Special acknowledgment should go to National Research Council (NRC) Research Grant 15-151 for securing SimaPro Software and Ecoinvent database to SDM lab at DMIE. 


\section{References}

1. ABD Rashid, A., Yusoff, S. and Mahat, N., "A Review of the Application of LCA for Sustainable Buildings in Asia". Advanced Materials Research, 724-725, 2013, pp.1597-1601.

2. Abergel, T., Dean, B. and Dulac, J. (2017). GLOBAL STATUS REPORT 2017. [online] United Nations Environment Programme.

3. Adalberth, K., "Energy use during the Life Cycle of Buildings: a Method". Building and Environment, 32(4), 1997, pp.317-320.

4. Asif, M., Muneer, T. and Kelley, R., "Life Cycle Assessment: A Case Study of a Dwelling Home in Scotland". Building and Environment, 42(3), 2007, pp.1391-1394.

5. Balasbaneh, A. and Marsono, A., "Life Cycle Assessment of IBS in Malaysia and Comparing Human Health on Timber and Concrete Precast". Research Journal of Applied Sciences, Engineering and Technology, 06 (24), 2013, pp. 4697-4702.

6. Blengini, G. and Di Carlo, T., "The Changing Role of Life Cycle Phases, Subsystems and Materials in the LCA of Low Energy Buildings". Energy and Buildings, 42(6), 2010, pp. 869-880.

7. Chiefsec.wpc.gov.lk. 2019. BUILDING SCHEDULE OF RATES-2019. [online] Available at: http://chiefsec.wpc.gov.lk/engi/en/wpcontent/uploads/2019/04/BSR-2019.pdf

8. Daily News E paper, 2019.Over Rs. 26 bn allocated for Uda Gammana.

9. Green Rating System for Built Environmentversion 2.0. (2018). 1st ed. Colombo: Green Building Council of Sri Lanka.

10. Kamalakkannan, S., Peiris, R. and Kulatunga, A., 2019. "Life Cycle Assessment in Ceramic Floor Tile Industry in Sri Lanka". In: International Conference on Industrial Engineering and Operations Management. Thailand.

11. Keoleian, G., Blanchard, S. and Reppe, P., "LifeCycle Energy, Costs, and Strategies for Improving a Single-Family House". Journal of Industrial Ecology, 4(2), 2000, pp.135-156.

12. Khasreen, M., Banfill, P. and Menzies, G., "LifeCycle Assessment and the Environmental Impact of Buildings: A Review". Sustainability, 1(3), 2009, pp.674-701.

13. Kumanayake, R. and Luo, H. "Cradle-to-Gate Life Cycle Assessment of Energy and Carbon of a Residential Building in Sri Lanka". Journal of the National Science Foundation of Sri Lanka, 46(3), 2018, p.355.

14. Reddy, L. P. M, S. and Palaniappan, S. "Applycation of Life Cycle Assessment for a Residential Building Construction". In: International Symposium on Life Cycle Assessment and Construction, 2012.

15. Ministry of Housing and Construction, Specifications For Building Works- Volume 1. Colombo: Institute for Construction Training and Development (ICTAD), 2004, pp.73-92.

16. Monahan, J. and Powell, J., "An Embodied Carbon and Energy Analysis of Modern Methods of Construction in Housing: A Case Study using a Lifecycle Assessment Framework". Energy and Buildings, 43(1), 2011, pp.179-188.

17. Peiris, R., Kulatunga, A. and Jinadasa, K., "Life Cycle Assessment of Semi-Conventional Roof Tile Manufacturing in Sri Lanka". In: 8th International Conference on Structural Engineering and Construction Management, 2017. Kandy, 2017.

18. Salzer, C., Wallbaum, H., Ostermeyer, Y. and Kono, J., "Environmental Performance of Social Housing in Emerging Economies: Life Cycle Assessment of Conventional and Alternative construction methods in the Philippines". The International Journal of Life Cycle Assessment, 22(11), 2017, pp.1785-1801.

19. Silvestre, J., Brito, J. and Pinheiro, M., Building's "External Walls in Life Cycle Assessment (LCA) Research Studies". In: Portugal SB10 - Sustainable Building Affordable to All. [online] Algarve, Portugal, 2010

20. Unhabitat.lk. 2017. UN-Habitat Sri Lanka | Indian Housing Project In Plantation Areas. [online]Availableat:<https:// unhabitat.lk/proje cts/active-projects/indian-housing-project-incentral-and-uva-provinces-2/>

21. Utama, A. and Gheewala, S., "Life Cycle Energy of Single Landed Houses in Indonesia". Energy and Buildings, 40(10), 2008. pp.1911-1916.

22. Utama, A. and Gheewala, S., "Indonesian Residential High-Rise Buildings: A life Cycle Energy Assessment". Energy and Buildings, 41(11), 2009, pp.1263-1268. 